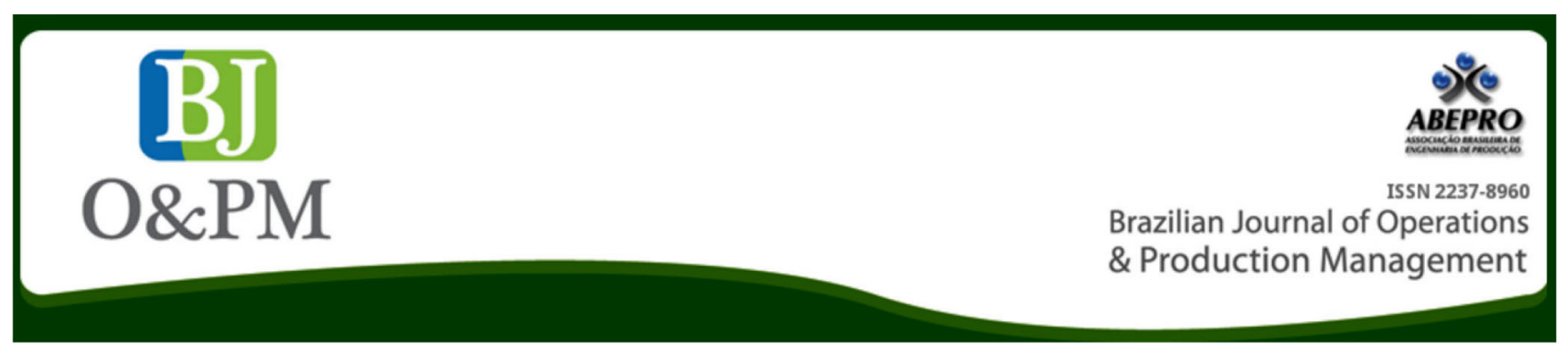

\title{
STRATEGIC TOOLS AND BUSINESS MODELING IN AN INFORMATION TECHNOLOGY FIRM
}

\author{
Felipe Hatzenberger Keller ${ }^{1}$, Everaldo Luis Daronco ${ }^{1}$, Marcelo Cortimiglia ${ }^{1}$ \\ 1 Universidade Federal do Rio Grande do Sul/Departamento de Engenharia de Produção
}

\begin{abstract}
Many small companies active in the segment of information and communication technology demonstrate difficulties in terms of expanding their business and increasing the product and service portfolio. In this context, this study aims to apply strategic tools and business model in a micro-segment of the software industry inserted into a huge market competition and low entry barriers. A qualitative research was carried out, unfolded in three stages: initial diagnosis, which is developed in the current map of the business model and analysed in the internal and external environments through tools such as PESTEL, Porter's 5 forces and SWOT matrix; critical analysis, when opportunities for improvement were identified based on analysis of the environment and questionnaires applied to current and potential customers and; restructuring and identifying improvements, a stage that includes the redesign of the idealized business model, stipulating coefficients of importance for further start-up study, by applying cross SWOT analysis. Among the main results to new technologies, media release, complementary services and support partnerships are adapted.
\end{abstract}

Keywords: Software; Business Model; Strategic Tools. 


\section{INTRODUCTION}

Information and communication technology (ICT) has had a significant progress in recent decades. Computers and mobile phones are items that show this strong growth. In about six decades, the computer that weighed about 32 tons with $180 \mathrm{~m}^{2}$ started to weigh 1.3 pounds in a size smaller than 0.1 $\mathrm{m}^{2}$ (Hamann, 2011). One of the most important branches of the ICT industry, software development, evolves at a similar pace. Computerized systems are directly responsible for significant increases in efficiency, productivity and agility for enterprises worldwide (Powell et Dent-Micallef, 1997) and are present in all sectors of the economy.

Because of these rapid and constant changes in scenery acting on any information, a company in the technology industry must keep up with technological advances, not to lose competitiveness to its competitors and to remain competitive in the market. In this context, business model and strategy are two essential concepts whose effective interplay is required for the success of any organization, and both have been widely employed in business management studies (Candeloro, 2009). The concept of business model has gained momentum in the late 90 's from the opportunities offered by the increased use of the internet and the creation of virtual enterprises (Tapscott, 2001). It describes the rationale on how an organization creates, delivers, and captures value (Teece, 2010) through a structure that assists entrepreneurs to think in more detail in the company's line of business and that creates value for the market, forcing it to rigorously analyse the business in which they operate and by identifying what features the products/services, it will satisfy the needs of its customers. The business model concept was definitely incorporated in the academic and professional lexicon from the 2000's, in particular, the phenomenon of Web 2.0, which allows more participatory users' actions to involve the web platform. Business modelling is particularly relevant for companies seeking to differentiate themselves through innovation because it allows them to relocate existing elements controlled by the company to identify and exploit new business opportunity resources.

On the other hand, a study in the strategic overview of the situation of the company is defined. According to Nicholas (2001), the concept of strategic planning is based on the inseparability between the organization and its environment. The strategic approach forces entrepreneurs to position themselves correctly in the face of situations, especially when they are facing uncertainty and turbulence in the environment, be it financially, or their internal activities and processes (Barbosa et Brondani, 2005). According to Teece (2010), the combination of strategic analysis in business modelling is necessary in order to protect the competitive advantage arising from the design and implementation of new business models.
Therefore, the deployment of strategic approach and tactical practices and operational guidelines, in the form of a business model is critical. On the other hand, one could argue that formal business modelling can provide key input for improving the strategic planning process itself. However, this topic is still recent in literature and in the practice of consulting firms. This paper aims to substantiate the hypothesis in terms of mutual reinforcement between these two conceptual approaches and present new strategic business opportunities for the company. The lack of a strategic plan aligned to business modelling is particularly relevant to the ICT industry. Although innovation is a competitive imperative, many companies active in this segment, especially smaller ones, show difficulty in terms of expanding their businesses and increasing their products and services portfolio (Deloitte, 2011). These firms face major challenges when seeking innovation and an improved service offering to leapfrog the intense competition that characterizes the ICT industry. Factors behind such challenges include lack of knowledge about the adequate techniques to generate innovation, difficulties in measuring innovation outcomes, and lack of resources to implement innovation efforts.

In this context, the study aims to investigate the relationship between strategic planning and business modelling in an acting company in the technology industry. More specifically, the paper discusses the application of the business model coupled with strategic tools, aimed at identifying opportunities in a study among microenterprises located in Porto Alegre (RS) whose primary function is the development of integrated business management systems that note the need for an increase in its portfolio of services.

The article is structured along the following sections. The conceptual framework is presented in Section 2. The methodological procedures are described in Section 3, while Section 4 presents the case study drawn from the results of the methodology. A conclusion closes the study in Section 5 .

\section{CONCEPTUAL FRAMEWORK}

The development of this work was based on the conceptual framework of strategic planning and business modelling. Therefore, these concepts and some of its applications are presented in the following sections.

\subsection{Strategic Planning}

Strategic planning (SP) is the concept of a management methodology that defines the direction in which an organization must follow. It is a proven technique that allows the creation of a projection and necessary adjustments by senior management. According to Maximiano (2006), "Strate- 
gic planning is the process of developing the strategy and defining the relationship between the organization and the environment. This process involves making decisions and setting behaviour that the organization will follow regarding the products and services it offers, as well as markets and customers it wants to reach".

Oliveira (2005) states that "strategic planning is a process and should be developed in order to achieve a future situation, applying the most efficient and effective resources of the company". For Oliveira (1997), the SP should allow uniting the strategic, tactical and operational definitions, so that the objectives of long and short term are reliable and faithful. Your application may be considered fundamental for a company inserted in a market with incredible rapidity of change in its profile and the economic, social, technological and political environments. Because of this, in 2002, the consultancy Bain \& Company identified the SP as the tool most used by 784 executives from Europe, USA and Asia (Mundstock, 2008).

Maximiano (2006) states that "understanding the competitive forces of a line of business is critical for the development of the strategy." To fully understand this, the five forces defined by Michael Porter in 1979 may help the identification of the external environment, analysing the attractiveness of a business segment or product (Aaker, 2007). Porter identifies five factors responsible for determining the competitiveness of the firms: the rivalry among competitors, bargaining power of suppliers, bargaining power of customers, threat of new entrants and threat of substitute products or services (Porter, 2008).

Another tool widely used in strategic studies in conjunction with other analytical tools is a PESTEL analysis, used to analyse situations which are beyond the control of the company. It aims to investigate the threats and opportunities that the company should avoid and enjoy. According to Faria (2010), "The PEST analysis is a method that allows the qualitative study of a given scenario, based on political $(P)$, economic $(E)$, social (S) and technology (T) factors, later supplemented with two factors: environment (E) and law (L). The analysis of these dimensions, difficult to quantify, combined with other methods of environmental analysis (internal and external factors) of an organization, enables the understanding of complex and constantly changing environments" and the information represents the preliminary analysis of the study.

A SWOT analysis is also part of the tooling available techniques for developing a strategic plan. This analysis is used to verify the organization's strategic situation in the environment in which it operates (Mccreadie, 2008). The term is an acronym of the words Strengths, Weaknesses, Opportunities and Threats. It is responsible for analysing the scene and list the opportunities and threats in the external environment with the strengths and weaknesses of the internal environment.
Rodrigues (2005) indicates that, insofar as the strengths and the critical success factors of the company are aligned to meet market opportunities, it will be competitive in the long term.

\subsection{Business model}

Business model (BM) is a fundamental concept that defines the organization for both the external public and its employees. It describes how the firm is structured for creating and delivering value (Campanha, 2012). Value, in this context, is understood not only in terms of strict tangible cost-benefit analysis, but also includes overall perceived quality and other intangible returns (Beulke et Mattuella, 2007). Not always, the quality envisioned by managers is the same as understood by consumers. There is a concept that defines the perceived customer value; each has his own perception and their value to the utility, according to assigned importance and the amount paid by him. According to Peter Drucker the business model should answer the following questions: "Who is the customer?", "What is the value to his customers?" and "How to generate cash from that deal?" (Neto, 2009).

For Schafer et al. (2005), the business model is a representation of choices of a company through logical and strategic choices based, to create and capture value within a value network. Teece (2010) adds by stating that "a BM demonstrates the way a business creates and delivers value to its customers. It also outlines the architecture of the revenues, costs and profits associated with the business". According to Luciano et Freitas (2004), the BM is a synthesized view of the company, where the roles, functions, features and individual and collective skills are examined so that the organization remains active in the market. Amit et Zott (2001) complete by stating that the "BM does not follow the flow of a product from creation to sale, but describes the steps that are performed to complete the transactions".

As well as the strategy, the BM diversifies, depending on the need of each organization. According Tim O'Reilly, CEO of O'Reilly, "there is not a unique business model. There are actually a lot of opportunities and plenty of options and we only discover them all" (Grando, 2011). For Andrade (2001), a model of clear and defined business becomes essential for strategic planning element, claiming it is an enterprise architecture in which the maximization of resources and core competencies are responsible for the creation of value for the organization.

Johnson et al. (2008) define the BM in four main elements that, together, are mutually dependent and defines the values for the company's value proposition to the customer, profit formula, key resources and key processes. According to Chesbrough et Rosenbloom (2002), a business model has the following, based on a model of innovation in the value 
proposition functions: growth strategies, value proposition, market segments, the structure of the value chain, revenue model and competitive strategies.

\subsection{Relationship between Strategic Planning and Business Model}

Strategic innovation can take the form of new products and services, by reconfiguring the traditional business model of a new market, technology or business plan, through the definition of a strategic frontier (Bate et Johnston, 2005). Chesbrough et Rosembloom (2002) indicate that the most palpable difference between the two concepts is that the business model works in the process of value creation for the customer, while the strategy captures value.

According to Teece (2010), combining strategy with business models can offer several competitive advantages for the company. It can be understood as a strategy to protect the competitive advantages arising from the results of the business model, displayed against the imitation of products and services from competitors. Thus, both strategic planning as the BM show to be essential tools for organizations working in the information technology sector, whereas low barriers to entry make it easier for new competitors to develop themselves.

Schafer et al. (2005) point out that the business model facilitates the analysis and validation of strategic choices and they cannot be defined in isolation, without consideration of the tactical and operational developments outlined in a BM. Casadesus-Masanell et Ricart (2002) confirm this view by defining business model as a direct reflection of a company's strategy. Andrade (2001) adds further, indicating that the revision of the business model is considered a stage of SP. For Osterwalder (2004), the BM acts as an intermediary between the SP and the implementation of the process as shown in Figure 1.

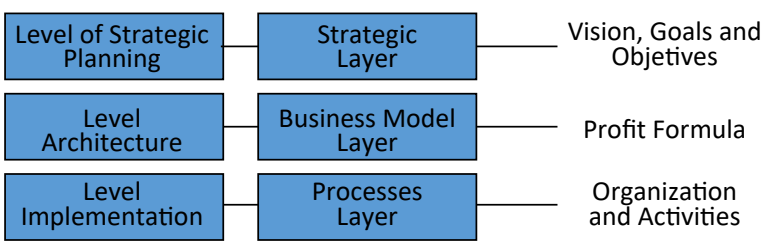

Figure 1. Business Model

Source: Adapted from Osterwalder (2004)

\subsection{Strategic Planning and Business Modelling for Information Technology Companies}

Demand for new products or services, to ease the entry of new competitors and reduced fixed costs are some fundamen- tals that expose the needs of the deployment of SP and BM tools in the IT sector companies. Hamel and Prahalad (1997) emphasize that the foundation of the strategy is to develop competitive advantages with greater speed than competitors mimic existing ones. This need is pressing in the IT sector.

It is noteworthy that the combined use of the concepts of SP and BM business has not yet been satisfactorily explored in the literature. Following, the results of the tools of information technology companies will be discussed, demonstrating its functionality not only for small businesses, but also results in large organizations.

One of the clearest examples of the importance of considering aspects of SP and BM in a technology business is Apple. The iPod, pioneer product of the current phase of the company, was achieved through the union of technical knowledge (especially on usability) and the understanding of consumer needs. The creation of a new value to many people, uniting hardware and consumption of music in motion, makes it easier for the customer to save money when buying music. The findings were defined based on detailed analyses of customers, defining the concepts of value and developing a new product that provides the expected values (Bate et Johnston, 2005). Moreover, the strategic considerations involved (control of the value chain, focusing on core competencies, pricing choices, differentiation against competitors, simplicity of design and product portfolio) were key to the success of the product (Sako, 2012).

Ambastha et Momaya (2004 apud Albano et al. 2012) analysed the competitive factors of an Indian software company. The low cost of operation and efficiency in delivery and competitive factors were identified. According to them, this force is not enough to call the company in a long run, if necessary, according to the study, increasing the outsourcing of services to more complex and higher value added projects. In view of the CEO of the Stratec software industry, Guilherme Barbassa, "The adoption of strategic planning establishes performance indicators for IT and allows evaluating the performance of the role in the area. This is what guides the development plans of information technology". Other relevant examples of potential combination of strategy and business modelling in the technology field include disintermediation via Web practiced by Dell and Amazon (Sako, 2012).

\subsection{Difficulties in implementing Strategic Planning in micro and small enterprises}

In the vast majority of micro and small enterprises, the owner is the partner responsible for major activities and the survival of the organization. Strong centralization under a single individual makes it difficult to strategically analyse and define new directions and innovations. Through a study by Krakauer et al. (2010), in 81 small and medium sized information technology companies, it was found that only $35 \%$ 
of respondents have to prepare a strategic plan structured in their companies and $17 \%$ have no worries despite being placed in a volatile market.

Machado (2006) indicates that the short time available for strategic activities, the multi-functionality of the leader and the lack of market information are the most common causes that lead companies not to not accomplish the SP. According to Souza et Qualharini (2007), "The vast majority of small organizations tend to ignore the need and the benefits of supporting their decision making processes in support of strategic planning, primarily because they considered themselves unable to absorb more of this activity". Pinheiro (1996) indicates that the non-use of managerial techniques is one of the factors responsible for a great loss of productivity, accompanied by the misapplication of material and financial resources.

According to Melo Neto (1997), 80\% of the difficulties encountered by companies hail from problems of a strategic nature, while only the remaining $20 \%$ are consequences of lack of resources. Micro and small enterprises that can survive in the market for over a year tend to be efficient in their daily activities and techniques, but end up making mistakes in strategic decisions. The lack of managerial knowledge and its actual consequences are relevant arguments to analyse these events.

Souza et Qualharini (2007) report a number of reasons behind the general lack of strategic capabilities in micro and small firms, which include: the potentiality of the company being a family model, since the informal language ultimately affects professional performance; organizational structure is extremely simple and often not clearly defined; access to technology is limited due to resources and the available working capital.

\section{METHODOLOGICAL PROCEDURES}

This section presents the scenario in which the company is included in the study and describes the methodology applied in this article.

\subsection{Scenario Study}

According to reports from the Brazilian Association of Software Companies (Associação Brasileira das Empresas de Software - ABES, 2012), in 2010 there were 8,478 software companies and economic exploitation in Brazil. Among them, it can be observed that $24.8 \%$ are dedicated to development and production, $51.8 \%$ for distribution and marketing and $23.4 \%$ to services (Brasscom, 2010).

According to the institute Gartner, the IT industry can achieve rates of $10 \%$ increase in its revenue in the current year (Soares,
2012). Among the technologies that will lead most of the budgets of the $\mathrm{ClO}$ in 2012, are solutions for cloud computing, mobility, social networking and Big Data management. According to studies pointed out by Getulio Vargas Fundation (FGV-EAESP, 2012), in 2011 the Brazilian companies allocated around 7\% of their revenue to expenditures and investments in Information Technology. According to the analyses of the Brazilian Association of Software Companies (Brasscom, 2010), the perspective from 2005 to 2010, the industrial sector accounts for $26 \%$ of Brazil's total IT revenue, followed by $23 \%$ in finance, $14 \%$ in services and $9 \%$ in the commercial sector. According to the association, the market for software and IT services consists of $94 \%$ of small and micro enterprises, a $5 \%$ average and only $1 \%$ large. It is a field of very strong competition, but promising, since, through the data collected by ABES, the software industry in Brazil ended the year 2011 with $12.4 \%$ growth in sales turnover and around 21,4 billion Reais. These values represent approximately $0.8 \%$ of national GDP and illustrate the importance and growth of supply management systems on the market.

ABES (2012) also reports that hardware sales (computers, servers, networking, peripherals and storage) represent $46 \%$ of total revenues in the Brazilian ICT market, the remainder being composed of $34 \%$ in services (training, planning, implementation, maintenance/support and operations) and $20 \%$ in software (applications, infrastructure and development).

This work was performed in a small information technology business located in Porto Alegre/RS and was inserted in the business of developing software for business management. It stands in the market for over 21 years for selling ERP systems at a low investment for small and mid-sized south and southeast of the country companies. Focuses exclusively on trade in eight different systems for small and medium businesses. Each software is aimed at a segment of business: commercial, retail, logistics, lawful and industrial. According to internal company reports, in 2011 , customers in the commercial sector accounted for $59 \%$ of sales, followed by $25 \%$ of manufacturing and $16 \%$ of services.

The company currently has around 70 monthly customers and, although it is a software industry, it falls into the category of services due to the full rent to be related to the license, maintenance and support of systems. It has five employees distributed in a simple and extremely functional organizational structure, in which decisions are centralized and completely dependent on the organization's executive director. All employees have the freedom to indicate improvements in products and participate in the development directly.

\subsection{Methodology}

About nature, this research is ranked as applied, because intends practical application of results obtained (Gil, 2007). 
The approach considered was the qualitative due to the fact that the purpose of the study was not to measure or treat employing statistical analysis of the acquired data, but use the inductive method, developing concepts and ideas on patterns found in the data, rather than collecting data to prove theories and pre-designed templates (Dantas et Cavalcante, 2006).

The study has an exploratory aim, for it seeks perceptions and understanding in terms of the general nature of the question under consideration, providing a space for interpretations on the subject (Dantas et Cavalcante, 2006). Action research was the procedure adopted, since it complements the research of knowledge production with the action of changing the reality of the company, seeking to perform practice known to act through the participation of people directly involved (Coughlan et Coghlan, 2002). This procedure is particularly useful when there is opportunity for the creation and articulation of new organizational knowledge (Pauleen et al., 2007). In our case, this knowledge translates directly into formalizing some aspects of SP and BM of the current company.

The study was split into three stages: (i) initial diagnosis; (ii) critical analysis and (iii) restructuring and identifying improvements, as illustrated in Figure 2.

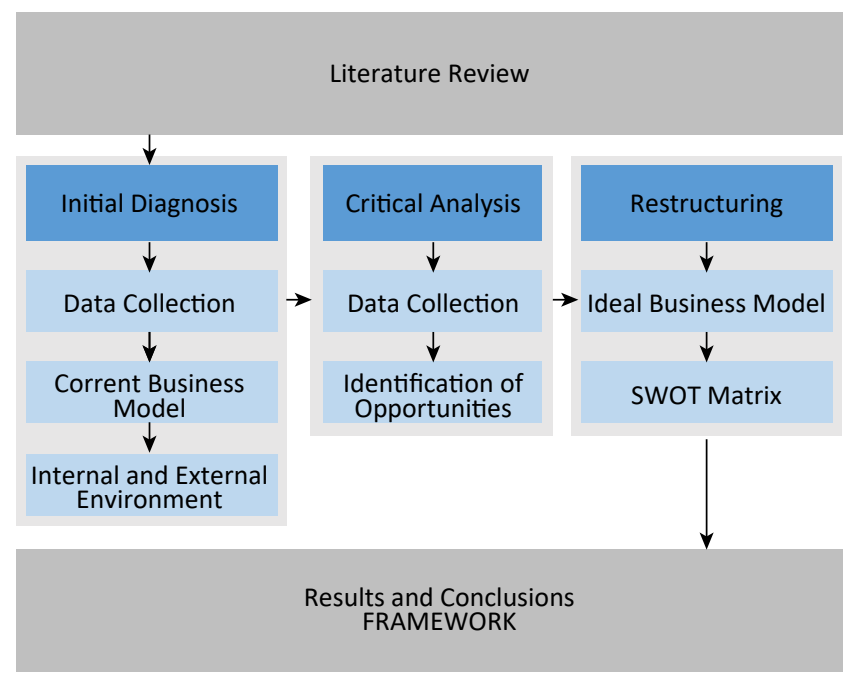

Figure 2. Research Methodology

Source: Authors

In the first stage, the initial diagnosis was performed in the company. This stage was divided into three substeps: i) data collection, ii) Mapping of the current business model and iii) analysis of the internal and external environment. Information was collected through internal indicators of the company and semi-structured interviews were conducted with managers. Two face interviews, lasting 12 to 20 minutes were conducted. The interviews were transcribed and their contents were comparative- ly analysed using techniques of Critical Discourse Analysis (Leitch et Palmer, 2010). The managers were asked about the current view on the company's business model. The business modelling was made from a modified structure of Johnson et al. (2008), Luciano et Freitas (2004) and Chesbrough et Rosenbloom (2002), divided it into four dimensions: value to the customer, profit formula, key resources and key processes, as illustrated in Figure 3. The interviews also worked as a substep for analysing the environment. Strategic tools that aim to record the directions identified by the company and its knowledge in terms of the current market were used. For the elaboration of the strategic diagnosis, the PESTEL analysis was used by means of the brainstorming technique among managers; for analysing the market segment, the five forces model of Porter was used, while the analysis of the microenvironment was made from the SWOT matrix.

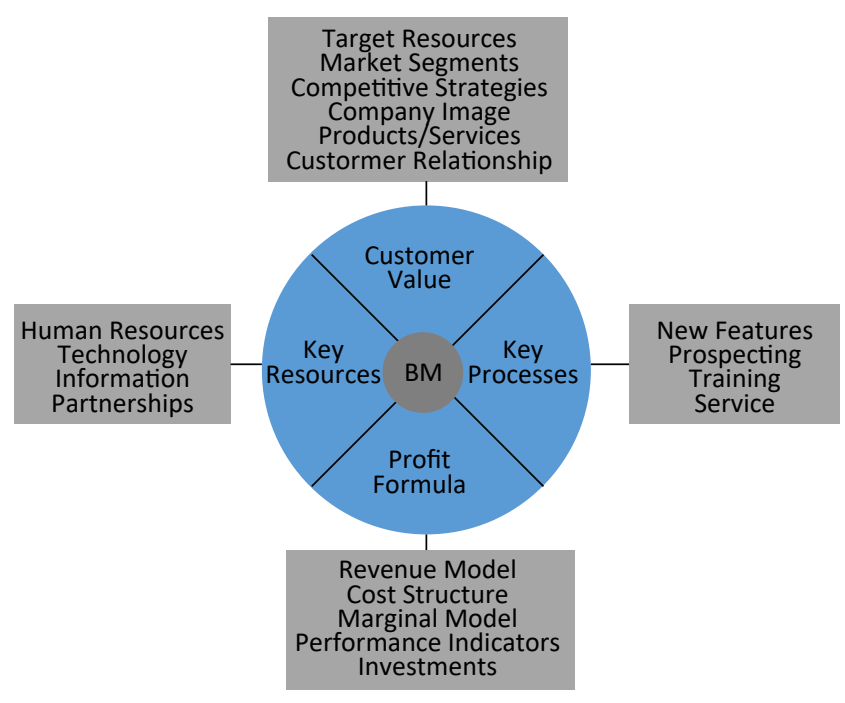

Figure 3. Business Model in an IT company

Source: Adapted Johnson et al. (2008), Luciano et Freitas (2004) and Chesbrough et Rosenbloom (2002)

The second stage corresponds to the critical analysis of the diagnosis and is split into two sub-steps: i) data collection through semi-structured interviews with current and potential customers, and ii) identification of opportunities for improvement and business innovation. The script for the semi-structured interviews with clients has been prepared in order to pass, indirectly, the main aspects for the development of business modelling, aiming to define the concept of values for the current and potential customers. This step was drafted seeking new products, markets, technologies, processes or resources. Thirty-four clients were interviewed over five weeks. Both current and potential clients were selected by proximity, timeliness and ease of access to managers, preferably seeking the segments with the greatest impact, such as industry, retail and wholesale. The interviews were con- 
ducted through face interviews, phone contacts or email. The interviews were transcribed and their content was analysed with techniques of Critical Discourse Analysis (Leitch et Palmer, 2010).

In the third stage, the model of idealized business and the restructuring of cross SWOT matrix were performed by prioritizing sectors for subsequent studies. The modifications were based on the results from the previous step and the opportunities identified were incorporated. To do so, based on the analysis of the internal and external environment and grounded in the literature, gaps were identified in order to best exploit the strengths and opportunities and tackle weaknesses, mitigating threats. The prioritization matrix was defined by one of the managers and can represent the degree of importance of each internal factor, depending on the external environment.

\section{RESULTS}

This section presents the practical application of the methodology and the results of the empirical research.

\subsection{Initial Diagnosis}

At this stage, the tools of strategic planning and business modelling have been applied founded only on information on the current customers and market knowledge on the part of management. Two interviews with company managers (president and sales manager) were performed.

\subsection{Mapping Business Model}

The stage of the business modelling aims to define the operating structure of the company based on the adapted model of Johnson et al. (2008), Luciano et Freitas (2004) and Chesbrough et Rosenbloom (2002) and aims at seeking the methods defined for the generation of revenue due to customer values currently understood. The model is divided into four dimensions: customer value - what is considered value in the products and services provided; profit formula - determining how a company generates earnings and their controls; Key resources - resources needed to deliver value to customers; and Key processes - necessary to deliver the values the client processes. The design of the current model is showed in Figure 4.
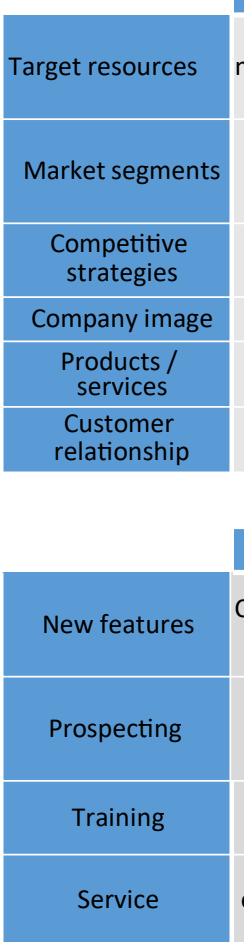

Implementation

\begin{tabular}{c} 
Costumer value \\
$\begin{array}{c}\text { Basic and advanced resources; fiscal } \\
\text { monitoring; flexibility for different working } \\
\text { methods }\end{array}$ \\
$\begin{array}{c}\text { Distribution; trade; pharmacies; logistics; } \\
\text { small industries; shutters industry; } \\
\text { parking; offices; legal }\end{array}$ \\
\hline $\begin{array}{c}\text { Low cost invested; technical support; } \\
\text { operating time }\end{array}$ \\
\hline Outlet for difficulties with computer \\
\hline ERP software; technical support \\
partnership \\
Key processes \\
\hline $\begin{array}{c}\text { Current costumer demand-development or } \\
\text { determination of appeal by the CEO }\end{array}$ \\
indications \\
\hline $\begin{array}{c}\text { Brief analysis of the working method for } \\
\text { system adaptation }\end{array}$ \\
Immediate solution using the telephone, \\
interference and superior aid \\
staks atement on the same system for
\end{tabular}

BM
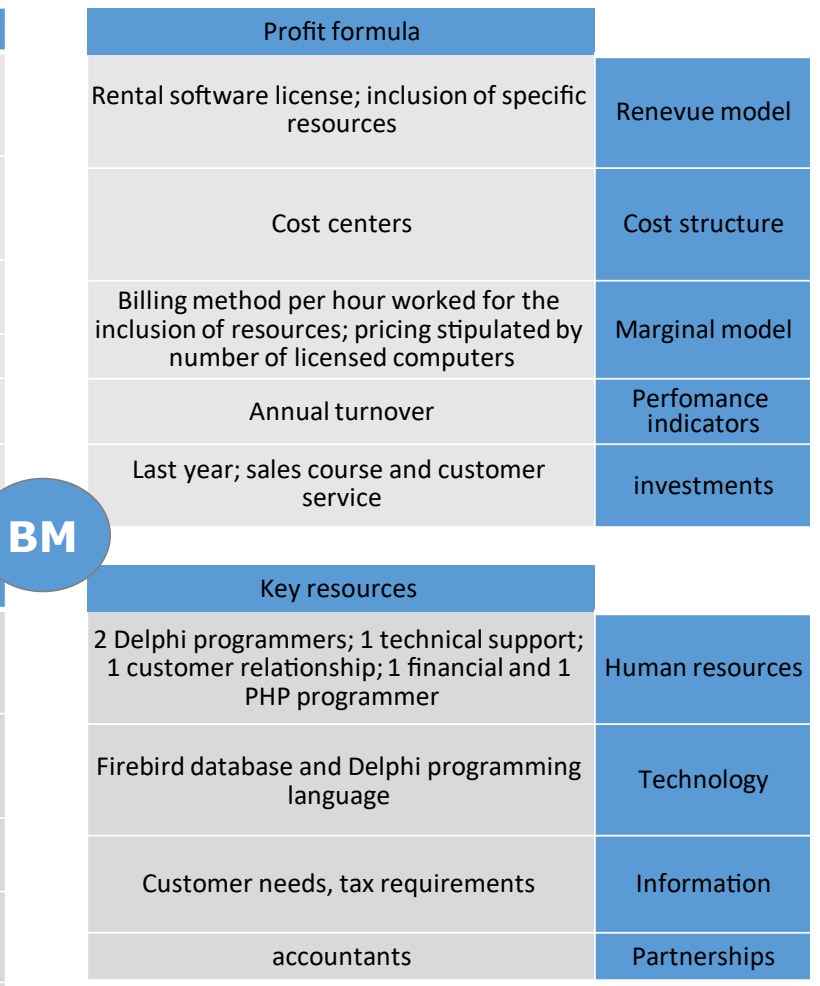

Figure 4. Current Business Model 
The company studied works in a segment in which current customers fall in the corporate micro, small or medium sized, in the profile of the states of Rio Grande do Sul, Santa Catarina and São Paulo, due to their fiscal framework. The company is responsible for the creation and development of software for Windows platform as well as installation, training and technical support assistance to customers. Products based on the premise that each company have their own way of working and are responsible for facilitating and automating processes and controls. Therefore, systems are designed with a focus on flexibility, adapting to diverse methods of operation. The company works with business segments: distribution, commerce, pharmacy, logistics, small industries, industrial shutters, parking lots, offices and legal. It works with the policy of monthly rental licenses, making it impossible to purchase the software and force the creation of a bond and closeness, representing a kind of escape from clients to face any kind of problems connected to the computer area. This lock-in mechanism, coupled with 21 years of market consolidation, is the main competitive strategy.

Currently the company has an office located in Porto Alegre and works with five employees, including two experts in programming in Delphi language systems, one person responsible for the technical support people, the financial sector and initiation in PHP programming, one company representative responsible for training, visits and demonstrations and one responsible for the commercial area. Recognizing the utmost importance, the company recently invested in the training of professionals responsible for customer service. Besides this, a sales course was held in order to find new distribution channels for products exhibition. The company has partnered with accounting firms, which indicate new customers in exchange for a greater ease in tax procedures of joint customers. The company works by indication customer or partner, which are the sources of information to the existing resources.

The process of product development is strongly reactive. From a recognized demand, the CEO determines and changes creations and runs or passes them to another programmer and after shutting them down, they should be forwarded to the responsible technical support. Currently, there is a large waiting list for changes and the development of new modules.

The process starts with a sale demonstration of the product, performed by two persons and with the use of a laptop. According to customers' interests, the second visit is focused on installation, firstly by training the people who will be in charge of departments and of the software settings, and by adapting the people to the process of the company.

The company works with two different revenue mechanisms: rental systems and payments by individual defendants, not by resources identified by the company as a possible source of value. Systems' rent prices start from an established base and increase the proportion of used computers, a situation that allows the marketing with all shapes and sizes. Single transaction pricing is based on the hourly cost of programming hours.

\subsection{Analysis of Internal and External Environments}

In the study of the external environment, the PESTEL analysis identifies opportunities and threats for the five dimensions of macroeconomics that are beyond the company's control: political, economic, social, technological, environmental and lawful together with the impact of each of the company under study, as illustrated in Table 1 . The data were defined by searching the current world scenario and two interviews with the managers of the company.

As shown in Table 1, there is a strong tendency of possibilities and lawful requirements for small and medium-sized businesses to automate their business, along with an individualized and personalized customer service, valuing the services currently provided by the company. The rapid advances in technology require ICT firms to maintain high levels of investment in R\&D, since customers tend to expect customized online systems due to the rapid growth and user acceptance of e-commerce. The technological monitoring by the government also has a negative impact, since the Public Digital Bookkeeping System (PDBS) will soon be required and will require adaptation of the ERP software to reporting to each accounting system.

To understand the competitive forces of the segment and the factors responsible for competitiveness among competitors, the analysis of the five forces of Porter (2008) was conducted, defining the rivalry between competitors, the bargaining power of suppliers, the bargaining power of customers, the threat of new entrants, threat of substitute products or services and their ability to affect each competitive force.

A SWOT analysis was developed in order to complete the external analysis tools, identifying strengths, weaknesses, threats and opportunities, and checking the status of the organization in the environment in which it operates.

The IT market has characteristic low entry barriers for new competitors and can be considered very competitive, whereas the minimum resources for insertion and initiation are low and there is no need for costly physical structure. However, the permanence of a company in this market is difficult due to the requirement of customers secured to their investments by consolidated companies. In contrast, technology evolution allows new entrepreneurs to achieve market share still not much explored, such as programming 
Table 1. PESTEL Analysis

\begin{tabular}{|c|c|c|}
\hline Dimension & Opportunities / Threats & Impact \\
\hline \multirow[t]{3}{*}{ Political } & \multicolumn{2}{|c|}{ Opportunities } \\
\hline & Tax reductions of government incentive & Availability of Resources for SMBs Investment \\
\hline & Incentives to Small Businesses & Ease of opening new businesses \\
\hline \multirow[t]{2}{*}{ Economic } & \multicolumn{2}{|c|}{ Threats } \\
\hline & World Economic Crisis & $\begin{array}{l}\text { Customer Billing reduction and consequent } \\
\text { reduction in investment in ERP }\end{array}$ \\
\hline \multirow[t]{4}{*}{ Social } & \multicolumn{2}{|c|}{ Opportunities } \\
\hline & Market demand for more individualized care & Greater value in service \\
\hline & \multicolumn{2}{|c|}{ Threats } \\
\hline & Increased e-commerce & System suitability with high costs \\
\hline \multirow[t]{5}{*}{ Technological } & \multicolumn{2}{|c|}{ Opportunities } \\
\hline & Rapid evolution of ICT & $\begin{array}{c}\text { Ease of smaller companies to acquire the tech- } \\
\text { nology needed to deploy an ERP }\end{array}$ \\
\hline & \multicolumn{2}{|r|}{ Threats } \\
\hline & \multirow[t]{2}{*}{ Rapid evolution of ICT } & Constant need for investment in R \& D \\
\hline & & $\begin{array}{l}\text { New trends and adaptation needs in the } \\
\text { company }\end{array}$ \\
\hline Environmental & - & \\
\hline \multirow[t]{5}{*}{ Lawful } & \multicolumn{2}{|c|}{ Opportunities } \\
\hline & electronic information requirements & Need to use ERP for companies of all sizes \\
\hline & Differentiations of interstate taxes & Tax Complexity \\
\hline & \multicolumn{2}{|c|}{ Threats } \\
\hline & Public Digital Bookkeeping System (PDBS) & Investment in the company with no return \\
\hline
\end{tabular}

for mobile devices (smartphones and tablets). The suitability of this technology requires investment of large companies that are reprogramming and adapting existing systems, representing a cost often impractical for developing organizations and has few key resources for innovation. Moreover, the large dependence on the CEO represents the typical case of a microenterprise and precedents open to the following consequences: labour is the limiting resource, vendor and product generator in any organization in the IT field, in which hiring a skilled worker requires care and loyalty; thus, they must be treated carefully to their permanence, as a good employee search prospects for growth and career plan, hardly found in companies of this size.

\subsection{Opportunities for improvement}

To check the current demand of the market in which the studied company is included, semi-structured interviews with thirty-four current and potential customers (twenty current and fourteen potential) were performed. One convenience sampling was used, aiming to capture general ideas, focus of the business segment. The interviews were made with the existing clients through face, phone or e-mail interviews while potential clients were approached by means of personal visits. The companies were chosen for the ease of access and opportunity for the manager, and the questions were used with the objective of associating the current characteristics of the systems and searching for others still unexplored, focusing on the requirements of pre-determined business model in order to update them with the actual need and requirement customer.

Of the total respondents, all follow the profile of managers and representatives of small and micro enterprises, located in Porto Alegre, Canoas, Cachoeirinha, Gravataí and São Leopoldo. The segments were: industry, retail and wholesale, which represent the main segments of interest. The face and telephone interviews basically followed the same profile: direct talks representing the interests of the companies in relation to the services provided by the company or by desirable initiation. Parallel to the research findings, analyses of the internal and external environment in conjunction with fundamentals of literature allowed the identification of gaps and opportunities related to resources, technologies, services and processes.

Regarding payment, some initial resistance from companies that do not have a bond with company studied can be perceived, by maintaining a fixed monthly allowance without dependency and expected completion. In the course of conversation, opinion has changed, due to the exploration of the importance of monitoring, updates and support available and recognized in this modality. 
For the correct and optimal pricing of a product or service, the correct cost control is of paramount importance. In the ICT environment, the method has better adhesion to the sector's activity-based, also known as $A B C$, because, by using this, indirect commercial production and support activities serve to support the strategy and form the cost basis of the process not only in the production centers. Using only the average demonstration, training, and support sales activities and considering a base salary of those involved, the current price of rent is below the minimum, representing loss in the first two months of lease. The minimum amount charged currently does not meet the basic costs, even with indirect evaluation.

Currently, the company has no regular marketing investments for dissemination of products. Interviewees suggest investing at least $3 \%$ of gross sales on advertising. Although the company only works with the method of prospecting by indication, considered the most reliable and suitable for the acquisition of a service implemented by the interviews, there is another method fairly addressed and indicated by some companies: participation in trade shows segments of interest. This approach brings together in one place many profiles of potential customers and it is one of the fastest and most efficient ways for the execution of media sales, and creates opportunities to learn from their competitors and offers their latest innovations. The website, on the other hand, despite being considered an excellent vehicle for dissemination, is not currently considered as a salesman of company products. Currently, customers do not come to the company only by this means of communication, even having already done work to improve the visualization of research sites. This media indicated by professionals expose the recognition of current customers through testimonials, to encourage, stimulate and make reliable services for those they still do not know. In addition, we must address one of the largest exhibition site in recognized organizations and of great importance in the business environment, establishing partnerships with some support to micro and small enterprises, such as Brazilian Micro and Small Business Support Service (Serviço Brasileiro de Apoio às Micro e Pequenas Empresas - Sebrae or other organizations. The sales strategy of visiting door to door does not have a very broad scope; however, due to direct contact with the owner of the property should bring good results.

Any company that wants to stay in the market often needs to analyse its direct and indirect competition. Benchmarking, be it competitive (with companies in direct competition) or generic (with leading organizations of the class and not competitors), may become valuable for improving processes, resources, distribution and further define specific strategies for differentiation and innovation, exploring most products and services that complement those provided by current company. The commercial sector stood out in interviews for favouring simple systems with clean, easy to handle and intuitive screens. This area was the main focus point improvement for existing customers, followed by the use of sectored training video lesson and instruction manual; inventory control of other branches; and administrative analysis and monitoring of industrial production. The latter enables a wider range of segments for midsize industries, since the lack of this specific feature avoids the marketing industry with this segment due to the peculiarity of production management. As they are mid-sized companies, their share in the revenue of the company represent a significant increase in average ticket, as for example, increased and more profitable sales.

Every year numerous analyst reports are created indicating technology trends for the coming years. These can be classified as fragile, or considered a bet, or solid, based on facts and real for the moment. Currently experts are stating the main solid and trends that are becoming requirement for many companies. Cloud computing or storage in the clouds, associated with the web platform, can mean more than reduced costs, representing business agility and safety. The use of mobile devices is increasing rapidly and their computational capacity is doubling every year. Companies are still reluctant to accept the use of such equipment, but it is expected that very soon the trend will come to organizations and even software programming in very different sectors of IT will adopt the app market model.

Through the interviews, the services currently provided were considered a valuable complement. It is thus validated the option for selling and installing hardware and the development of management information system sites, providing the sale by e-commerce. A study to examine the feasibility of hiring skilled labour to initially meeting the demands of current customers and then start the external disclosure was identified, thus transforming the growth of e-commerce threat into an opportunity. Currently outsourcing has become common and beneficial to companies of all sizes, enabling a more specialized and available personnel to be used as labour in cases of limited human and technical resources. The company has studied programming as a limiter for the opening of new markets and even as a demand from existing customers' factor. The ability to work in partnership with other companies, consultants, accountants - not including benchmarking with competitors - can become valuable when these demands become value-adding and can contribute significantly in the distribution and sale of products. In the case analysed, benchmarking, coupled with outsourcing, can act in the development of e-commerce, worked together with the system marketed by Serkell.

In three years, the company has increased its effective staff by $150 \%$. It is possible to consider as justifying a significant increase in demand in recent years, mainly due to innovations 
developed by the federal government, such as electronic invoice. The rapid progress happened naturally and gradually and the demand is still growing, but more slowly. It was noted the necessity of planning for a growth plan based on sales targets, satisfaction indicators, control of incoming and outgoing clients with detailed analysis of each cancellation, investment disclosure exploiting the resources and facilities and encouraging more partnerships that can stimulate a significant increase in demand and, consequently, the revenues of the organization, allowing hiring more programmers.

Employee turnover requires constant attention of leaders in any organization. The knowledge gained by them and added to the products may not be owned by the developer, but by the organization. The known knowledge management is a method of business management that focuses on ways to manage information and assign them to the company. By using this method, a major weakness is suppressed. The knowledge of the CEO will be passed and its current dependence for the progress of the work will be eliminated, but it can also be used as motivation for growth in the company and greater valuing employees.

\subsection{Restructuring}

The stage of diagnosis was the basis for the identification of new opportunities, both internal and external, and for improvements in resources, technologies, services and processes provided by the company under study. Parallel to this, the simple application of a business model aimed the gap that was not explored adequately in the current functioning of the organization. As an example, it is possible to mention the marginal model and analysis of current costs, which form the basis of prices and costs for activities.

This step consists of the application of cross SWOT matrix, which has the strengths, weaknesses, threats and opportunities reassessed, and the redesign of the business model, designed to implement the identified improvements, offers all the opportunities identified in the previous step.

Figure 5 refers to the redesign of the business model devised by implementing all the improvements defined during the study and highlights by means of underlined words, all changes made to the previous front of BM (Figure 4). The dimension "customer value" highlights how major changes are made, such as the insertion of sites and e-commerce tools in providing products and services of the company, followed by the tracking feature of industrial production functionality that could open a new the target market segment. For the dimension "profit formula", the calculation to change the initial base value can be considered the most impactful between changes, based on the hourly cost of each step of the process and people involved. The "key features" can be con- sidered more significant changes for the company, including new employees, adopting new technologies, partnerships and outsourcing. For the dimension "key processes", the use of video lessons will facilitate training and new methods of prospecting should raise demand for products.

Figure 6 presents the restructuring of the SWOT matrix, developed in the method of intersection between the internal and external environments. Its main function at this stage is to prioritize the areas of most striking focus for further continuation of the work in implementing improvements. For development, one of the managers used the logic importance of the internal environment in the face of opportunities and threats in the external environment, assigning values of $0,3,6$ and 9 . It can be seen that the electronic requirements by the government setting for the best opportunity for growth and great competition is seen as the main threat and deserves priority in feasibility studies. Internally, the payment method currently used was the main strength of the organization. Driven only by the use of the Windows platform, the quadrant Opportunities $x$ Weaknesses represented the largest sum, thus indicating that the company is still in the growth stage, seeking partnerships for innovation and expansion.

\section{CONCLUSION}

The union of strategic tools with business modelling has contributed significantly to the outcome of the study. From the initial goal of applying tools enabling the identification of opportunities and increasing its portfolio of services, this accession, together with the application of research aiming to define values at current and potential customers, allowed more precision in terms of the analysis and assignment of improvements and opportunities in almost all sectors of operation of the company, obtaining, in this way, the purpose intended.

The main limitations of the study relate to applied research and indicated improvements. The first approach due to the difficulty of the managers for a large number of responses, and the second due to idealizations according to the environment in which the company operates, and is not designed for a deeper evaluation and validation by the organization. Therefore, the Business Model finally mapped still requires approval, seeking financial and market, both customers and suppliers viabilities.

The proposed model improvements sought to define the support of strategic tools, noting the great difficulty found in the current company: a small business inserted into a market with huge competition. The concept is not only deployed in the market organizations, but also in developing companies of all sizes and structures. 


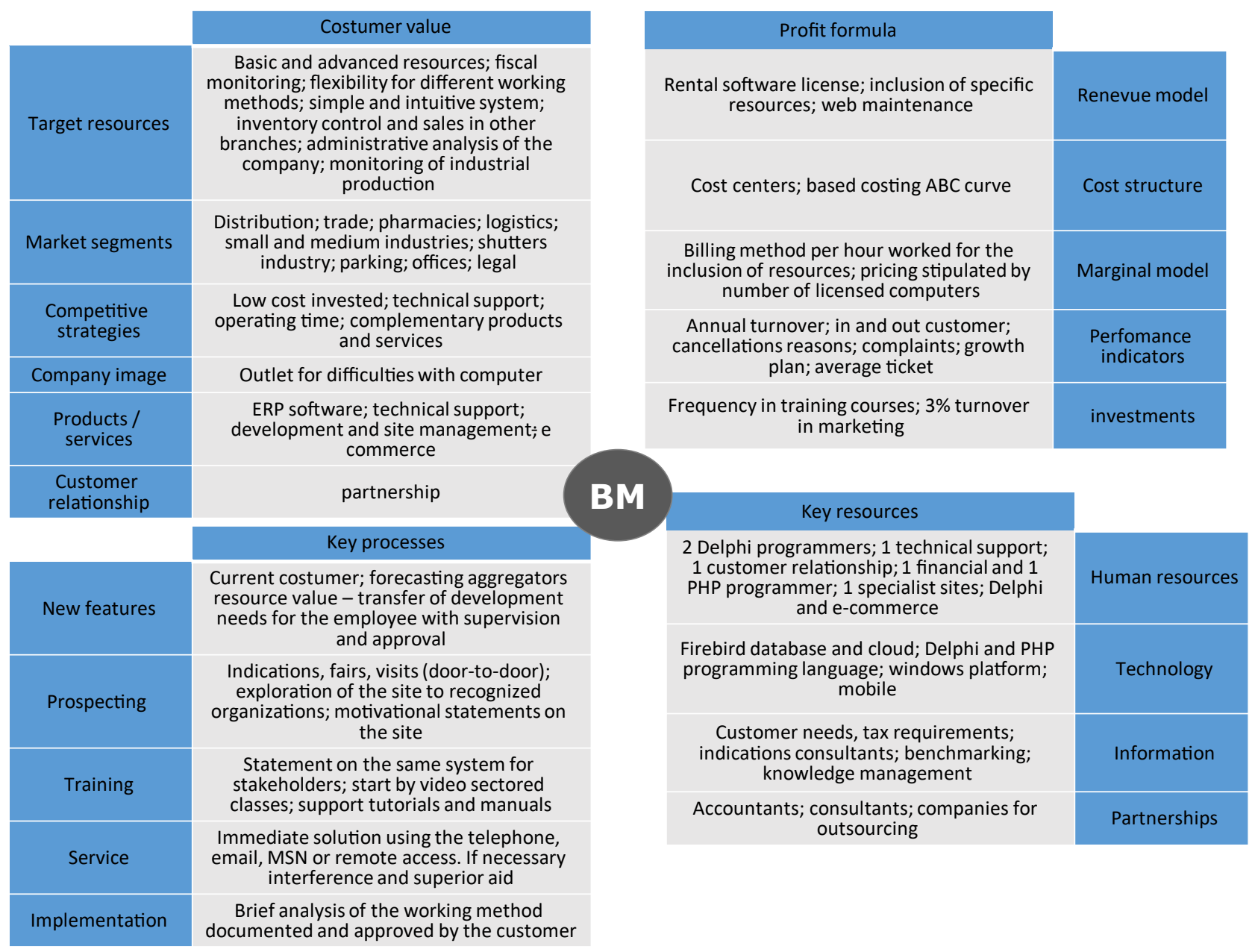

Figure 5. business model designed Source: Authors

\section{REFERENCES}

Aaker, D.A. (2007), Administração Estratégica de Mercado. 7. ed. Cidade: Bookman.

ABES Software. (2012), Mercado Brasileiro de Software - Panorama e Tendências 2012. Partner Sales. <http://www.partnersales.com.br/noticia/7707/abes-anuncia-que-o-mercado-de-software-no-brasil-superou-12-em-2011>. [13 april 2012].

Albano, C.S., Almeida, M.I.R. and Garcia, F.T. (2012), Monitoramento Ambiental Organizacional no processo de Planejamento Estratégico em Pequenas Empresas de Software. Revista da Micro e Pequena Empresa, Vol. 6, No. 1, pp. 56-71.

Amit, R. and Zott, C. (2001), Value creation in e-business. Strategic Management Journal, Vol. 22, No. 6, p. 513.

Andrade, M.G. (2001), Impacto da Internet na Indústria Farmacêutica: novo modelo de negócios na economia da informação. Dissertação (Mestrado). São Paulo: EAESP/FGV.

Barbosa, E.R. and Brondani, G. (2005), Planejamento Estratégico Organizacional. Revista Eletrônica de Contabilidade.
Curso de Ciências Contábeis UFSM, Vol. 1, No. 2.

Bate, J.D. and Johnston, R.E. (2005), Strategic frontiers: the starting-point for innovative growth. Strategy \& Leadership, Vol. 33, No. 1, pp. 12-18.

Beulke, R. and Mattuella, J.L. (2007), O preço e o Valor Percebido: uma abordagem mercadológica. REDES, Vol. 12, No. 2, pp. 73-91.

Brasscom (2010), Índice Brasscom de Convergência Digital, RCR Consultoria e Gestão Empresarial, São Paulo.

Campanha, N. (2012), Modelo de Negócio. Cultura Mix. Available at: <http://www.culturamix.com/dinheiro/negocios/modelo-de-negocio>. [25 May 2012].

Candeloro, R. (2009), Modelo de Negócio e Estratégia, você tem? Administradores.com, o portal da administração. Available at: <http://www.administradores.com.br/informe-se/ artigos/modelo-de-negocio-e-estrategia-voce-tem/27263/> [25 May 2012].

Casadesus-Masanell, R. and Ricart, J.E. (2002), From Strategy to Business Models and onto Tactics. Long Range Plan- 


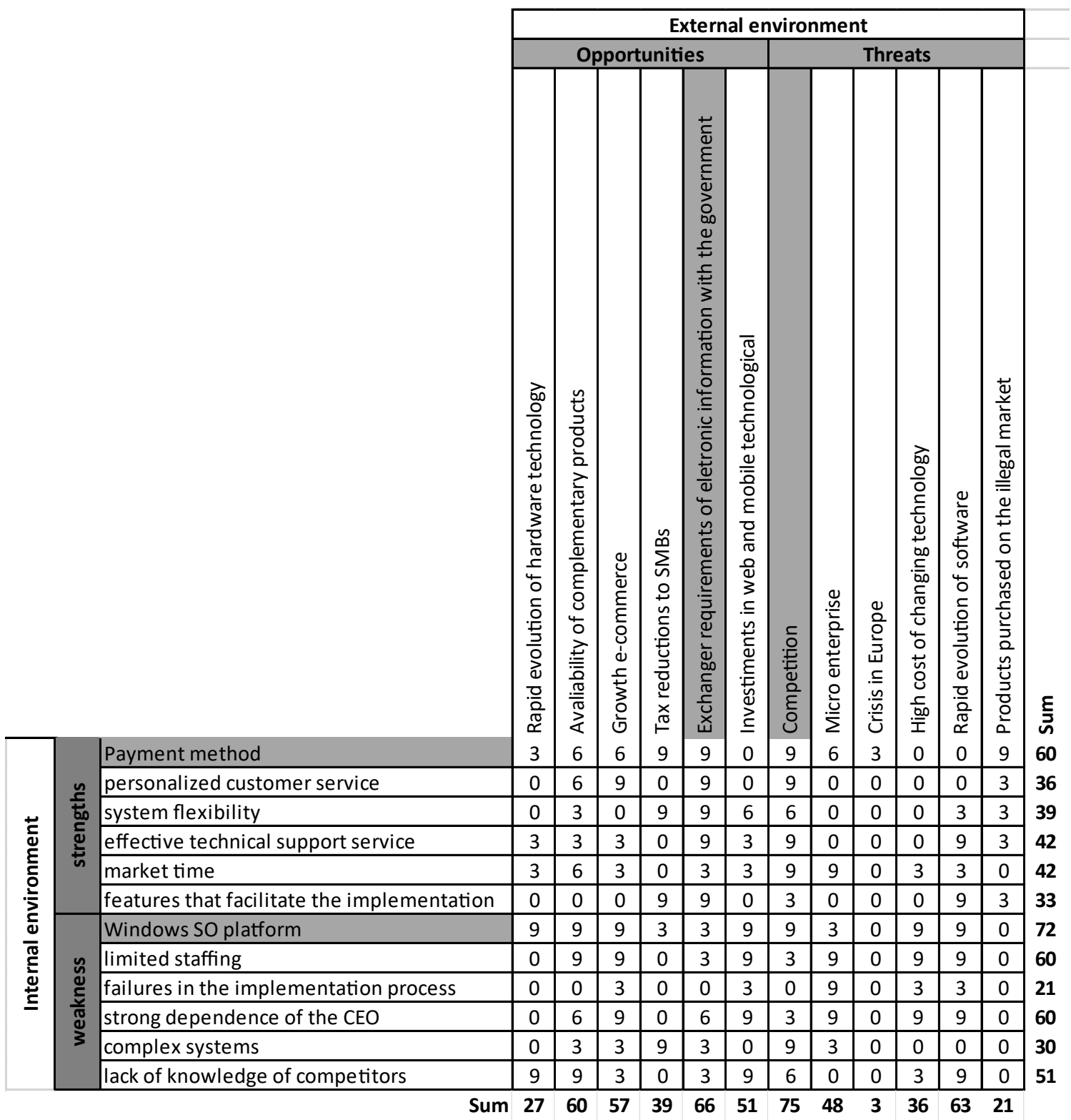

Figure 6. SWOT Analysis

Source: Authors

ning, Vol. 43, No. 3, pp. 195-215.

Chesbrough, H. and Rosenbloom, R.S. (2002), The role of the business model in capturing value from innovation - evidence from Xerox Corporation's technology spin-off companies. Industrial and Corporate Change, Vol. 11, No. 3.

Coughlan, P. and Coghlan, D. (2002), Action research for operations management. International Journal of Operations \& Production Management, Vol. 22, No. 2, pp. 220-240.

Dantas, M. and Cavalcanti, V. (2006), Pesquisa qualitativa e pesquisa quantitativa - Recife. Available at: <pt.scrbd.com/ doc/14344653/Pesquisa-qualitativa-e-quantitativa>. [15 june 2012].
Deloitte (2011), A receita da rentabilidade para expandir os negócios: Um estudo sobre as PMEs que mais crescem no Brasil. <https://www2.deloitte.com/content/dam/Deloitte/ br/Documents/Conte\%C3\%BAdos/PMEs/PME2011.pdf>.

[20 August 2012].

Faria, C. (2010), Análise PEST. Infoescola - Navegando e Aprendendo. Available at: <http://www.infoescola.com/administracao_/analise-pest/>. [19 June 2012].

FGV-EAESP - Fundação Getúlio Vargas, Escola de Administração de Empresas de São Paulo. (2012), Mercado Brasileiro de TI e Uso nas Empresas. São Paulo.

Gil, A.C. (2007), Métodos e Técnicas de Pesquisa Social. 5a 
ed. São Paulo: Atlas.

Grando, N. (2011), A importância da modelagem de negócios. Blog sobre pessoas, negócios e tecnologia. Available at: <http://neigrando.wordpress.com/2011/05/05/a-importancia-da-modelagem-de-negocios/>. [23 May 2012].

Hamann, R. (2011), A evolução dos computadores. Tecnomundo. Available at: <http://www.tecmundo.com.br/ infografico/9421-a-evolucao-dos-computadores.htm> june 2012].

Hamel, G. and Prahalad, C.K. (1997), Competindo pelo futuro. 4. ed. São Paulo: Campus.

Johnson, M.W., Christensen, C.M., Kagermann, H. (2008), Reinventing your Business Model. Harvard Business Review, Vol. 86, No. 12.

Krakauer, P.V.C., Porto, M.C.G, Fischmann, A.A. et al. (2010), Planejamento em Pequenas e Médias Empresas: estudo quantitativo em empresas brasileiras de tecnologia de informação. Revista Espacios, Vol. 33, No. 7.

Leitch, S. and Palmer, I. (2010), Analysing texts in context: current practices and new protocols for Critical Discourse Analysis in Organization Studies. Journal of Management Studies, Vol. 47, No. 6, pp. 1194-1212.

Luciano E.M. and Freitas H. (2004), Economia digital, Modelos de Negócios e Legitimação de Componentes, Congresso Anual de Tecnologia da Informação. Available at: <http:// www.ufrgs.br/gianti/files/artigos/2004/2004_155_CATI.pdf>. [12 September 2012].

Machado, J.R. (2006), Planejando a estratégia de pequenos negócios. Rio de Janeiro: Qualitymark.

Maximiano, A.C.A. (2006), Teoria geral da administração: da escola científica à competitividade em economia globalizada. São Paulo: Atlas.

Mccreadie, K. (2008), A Arte da Guerra SUN TZU: uma interpretação em 52 ideias brilhantes: 1a ed. São Paulo: Globo.

Melo Neto, J.F. (1997), Pesquisa Ação (aspectos práticos da pesquisa-ação nos movimentos sociais populares e em extensão popular) - Universidade Federal da Paraíba, Grupo de pesquisa em Extensão Popular. Available at: <http://www. prac.ufpb.br/copac/extelar/producao_academica/artigos/ pa_a_pesquisa_acao.pdf> [16 June 2012].

Mundstock, P. (2008), Relação entre planejamento estratégico e desempenho superior. Dissertação (Mestrado). Porto Alegre: PPGA/UFRGS.

Neto, J.G.J. (2009), Modelo de Negócios. Lições de Empreendedor. Rio de Janeiro.

Oliveira, D.P.R (2005), Planejamento estratégico: Conceitos, metodologia prática. 22. ed. Atlas, São Paulo.
Oliveira, D.P.R. (1997), Excelência na administração estratégica. São Paulo: Atlas.

Osterwalder, A. (2004), The business model ontology a proposition in a design science approach. Tese. Universite de Lausanne Ecole des Hautes Etudes Commerciales.

Pauleen, D.J., Corbitt, B. and Yoong, P. (2007), Discovering and articulating what is not yet known - Using action research and grounded theory as a knowledge management strategy. The Learning Organization, Vol. 14, No. 3, pp. 222-240.

Pinheiro, M. (1996), Gestão e desempenho das empresas de pequeno porte. Tese (doutorado). São Paulo, FEA-USP.

Porter, M.E. (2008), The Five Competitive Forces that Shape Strategy. Harvard Business Review.

Powell, T.C. and Dent-Micallef, A. (1997), Information technology as competitive advantage: the role of human, business, and technology resources. Strategic Management Journal, Vol. 18, No. 5, pp. 375-405.

Rodrigues, M.V. (2005), Método para determinação da escala de prioridade de ações estratégicas fundamentado no grau de inter-relacionamento entre os indicadores das perspectivas do Balanced Scorecards e o valor econômico adicionado. Tese (doutorado) - Programa de Pós-Graduação em Engenharia de Produção, UFSC.

Sako, M. (2012), Business models for strategy and innovation. Communications of the ACM, Vol. 55, No. 7, pp. 22-24.

Schafer, S.M., Smith, H.J. and Linder, J.C. (2005), The power of business models. Business Horizons, Vol. 48, No. 3, pp. 199207.

Soares, E. (2012), TIC do Brasil deverá crescer acima de 10\% em 2012. NBusiness, 2012. Available at: <http://computerworld.com.br/negocios/2012/01/10/tic-do-brasil-devera-crescer-acima-de-10-em-2012> [9 June 2012].

Souza, W. and Qualharini, E. (2007), O planejamento estratégico nas micro e pequenas empresas. III Workshop Gestão Integrada: Riscos e Desafios. São Paulo. Available at: <http:// tupi.fisica.ufmg.br/ michel/docs/Artigos_e_textos/Empresa_familiar/planejamento_estrategico_nas_mpes.pdf $>$. [12 September 2012].

Tapscott, D. (2001), Rethinking Strategy in a Networked World, Strategy + Business, Vol. 24, pp. 1-8.

Teece, D.J. (2010), Business Models, Business Strategy and Innovation. Long Range Planning, Vol. 43, No. 2-3, pp. 172194. 